\title{
Pregnancy and delivery rates after vitrification of in vitro-produced Nelore (Bos indicus) embryos under field conditions
}

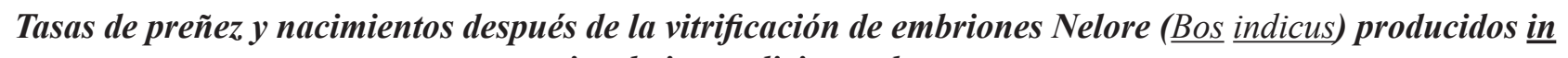
vitro bajo condiciones de campo


condições de campo

Lucas C Pereira, MV, MSc; José C Ferreira-Silva*, MV, MSc; Ludymila F Cantanhêde, Biol, MSc; Sarah R L Basto, Biol, MSc; Humberto F Veloso Neto, MV, MSc; Marcelo T Moura, Biol, Dr; Marcos Antonio L Oliveira, MV, PhD.

Laboratório de Biotécnicas Reprodutivas, Departamento de Medicina Veterinária, Universidade Federal Rural de Pernambuco, Brasil.

(Received: February 21, 2017; accepted: March 5, 2018)

doi: 10.17533/udea.rccp.v32n1a05

\begin{abstract}
Background: Cryopreservation preserves cellular viability under low temperatures, resulting in diminished intracellular enzymatic activity and reduced cellular metabolism that ultimately allows preserving genetic material for indefinite periods of time. Embryos submitted to cryopreservation suffer from considerable morphological and functional damage, resulting in reduced survival and development rates. Objective: To evaluate pregnancy and delivery rates of in vitro-produced (IVP) Nellore (Bos indicus) embryos after vitrification under field conditions. Methods: The IVP embryos at blastocyst (Bl) and expanded blastocyst $(B x)$ were transferred fresh $(n=137)$ or after vitrification $(n=127)$. Results: Pregnancy rates at $35 \mathrm{~d}$ for fresh embryos were lower in $\mathrm{Bl}(41.6)$ than in $\mathrm{Bx}(60.9)(\mathrm{p}<0.05)$. After vitrification, pregnancy rates were similar at $35 \mathrm{~d}$ between $\mathrm{Bl}(38.0)$ and $\mathrm{Bx}(47.6)(\mathrm{p}>0.05)$. Pregnancy loss at $60 \mathrm{~d}$ were similar $(\mathrm{p}>0.05)$ for both fresh (Bl: 3.1 and $\mathrm{Bx}: 4.8)$ and vitrified embryos (Bl: 1.9 and $\mathrm{Bx}: 4.7)$. Delivery rates were similar between groups ( $>0.05$ ). Conclusion: Both pregnancy and delivery rates of Bos indicus IVP embryos vitrified under field conditions are indistinguishable from fresh embryos.
\end{abstract}

Key words: cattle reproduction, cryobiology, cryoinjury, cryotolerance, embryo surplus, embryo transfer.

a To cite this article: Pereira LC, Ferreira-Silva JC, Cantanhêde LF, Basto SRL, Veloso Neto HF, Moura MT, Oliveira MAL. Pregnancy and delivery rates after vitrification of in vitro-produced Nelore (Bos indicus) embryos under field conditions. Rev Colomb Cienc Pecu 2019; 32(1):43-49.

* Corresponding author: José Carlos Ferreira-Silva, Laboratório de Biotécnicas Reprodutivas, Departamento de Medicina Veterinária, Universidade Federal Rural de Pernambuco, Av. Dom Manoel de Medeiros, s/n Dois Irmãos, CEP: 52171-900 Recife-PE, Brasil. Tel.: +55-081-33206414. E-mail: carlos.ztec@ gmail.com 


\begin{abstract}
Resumen
Antecedentes: La criopreservación se caracteriza por el mantenimiento de la viabilidad celular a bajas temperaturas, resultando en reducido metabolismo y actividad enzimática intracelular, lo que permite la preservación del material genético por períodos de tiempo indefinidos. Los embriones sometidos a ésta técnica sufren daños morfológicos y funcionales considerables, dando como resultado una sobrevivencia y tasas de desarrollo reducidas. Objetivo: Evaluar la tasa de preñez a partir de embriones Nelore (Bos indicus) producidos in vitro (IVP) después de la vitrificación bajo condiciones de campo. Métodos: Embriones IVP en los estadios de blastocisto (Bl) y blastocisto expandido (Bx) se transfirieron en fresco ( $\mathrm{n}=137)$ o después de la vitrificación $(n=127)$. Resultados: La tasa de preñez a los 35 d fue menor para los embriones transferidos en fresco en fase $\mathrm{Bl}(41,6)$ en relación con los $\mathrm{Bx}(60,9)(\mathrm{p}<0,05)$. Después de la vitrificación, las tasas de preñez a los 35 d fueron similares entre $\mathrm{Bl}(38,0)$ y $\mathrm{Bx}(47,6)(\mathrm{p}>0,05)$. Las pérdidas de preñez a los $60 \mathrm{~d}$ fueron similares $(\mathrm{p}>0,05)$ tanto para embriones en fresco en $\mathrm{Bl}(3,1)$ y $\mathrm{Bx}(4,8)$ como para los vitrificados $(\mathrm{Bl}$ : 1,9 y Bx: 4,7). Las tasas de nacimiento fueron similares entre los grupos ( $p>0,05)$. Conclusión: Las tasas de preñez y nacimiento de embriones IVP vitrificados de Nelore (Bos indicus) bajo condiciones de campo son semejantes a las de embriones en fresco.
\end{abstract}

Palabras clave: criobiología, crioinjuria, criotolerancia, embriones sobrantes, reproducción de ganado, transferencia de embriones.

\title{
Resumo
}

Antecedentes: A criopreservação é caracterizada pela manutenção da viabilidade celular em baixas temperaturas, resultando em atividade enzimática intracelular e metabolismo celular reduzido, que permite a preservação do material genético por períodos indefinidos de tempo. Embriões submetidos à criopreservação sofrem danos morfológicos e funcionais consideráveis, resultando em sobrevivência reduzida e menores taxas de desenvolvimento. Objetivo: Avaliar a taxa de prenhez a partir de embriões Nelore (Bos indicus) produzidos in vitro (IVP) após a vitrificação sob condições de campo. Métodos: Embriões IVP nos estádios de blastocisto (Bl) e blastocisto expandido $(\mathrm{Bx})$ foram transferidos a fresco $(\mathrm{n}=137)$ ou depois da vitrificação $(\mathrm{n}=127)$. Resultados: A taxa de prenhez aos 35 d foi menor para os embriões transferidos a fresco na fase de Bl $(41,6)$, em relação aos $\mathrm{Bx}(60,9)(\mathrm{p}<0,05)$. Apos a vitrificação, as taxas de prenhez foram semelhantes aos $35 \mathrm{~d}$ entre $\mathrm{Bl}(38,0)$ e $\mathrm{Bx}(47,6)(\mathrm{p}>0,05)$. As perdas de prenhez aos $60 \mathrm{~d}$ foram semelhantes $(\mathrm{p}>0,05)$ tanto para embriões a fresco nos estádios de Bl $(3,1)$ e Bx $(4,8)$, e vitrificados em Bl $(1,9)$ e Bx $(4,7)$. As taxas de nascimentos foram semelhantes entre os grupos $(\mathrm{p}>0,05)$. Conclusão: As taxas de prenhez e nascimentos dos embriões IVP vitrificados de Nelore (Bos indicus) sob condições de campo é semelhante àquela dos embriões a fresco.

Palavras-chave: criobiologia, crioinjúria, criotolerância, embriões excedentes, reprodução de gado, transferência de embriões.

\section{Introduction}

Cryopreservation is a method that maintains cellular viability under low temperatures, resulting in diminished intracellular enzymatic activity and reduced cellular metabolism that ultimately allows preserving genetic material for indefinite periods of time (Seidel, 1996). This technique has applicability both on scientific and commercial settings (Dattena et al., 2004).

Despite the differences in cryopreservation methodologies, all include temperature lowering, dehydration by cryoprotectants, freezing and thawing
(Mara et al., 2013). Vitrification was developed as an alternative to increase cryotolerance for early cleavage embryos. This process consists of embryo dehydration by rapid exposure to a cryoprotectant solution of high molecular weight and direct immersion in liquid nitrogen (Vajta et al., 2000).

Embryos submitted to cryopreservation suffer from considerable morphological and functional damage, resulting in reduced survival and developmental rates. Embryonic viability after cryopreservation depends upon embryo source (in vivo vs in vitro), quality, and developmental stage (Leibo et al., 1993, 1996). In vitro produced (IVP) embryos submitted 
to cryopreservation yield lower pregnancy rates than their in vivo counter-parts, possibly due to increased lipid content and smaller inner cell mass (Massip, 2001). Bovine embryo production system (in vitro vs in vivo), and breed (Bos indicus or Bos taurus breeds) are two major factors that affect embryo cryotolerance (Visitin et al., 2002).

Embryo vitrification has received great attention in the last decade as an attractive alternative to conventional freezing due to reduced costs, labour and overall simplicity (Kuwayama et al., 2005; Vajta et al., 2006; Sanches et al., 2013; Kocyigit and Cevik, 2015). Moreover, it is considered an efficient technique by avoiding the formation of intra and extracellular ice crystals, diminishing damage to membranes and cellular organelles. However, despite significant progress in recent years, embryo cryopreservation in different domestic species does not hold standard practices and similar results (Prentice and Anzar, 2010), since IVP embryos remain less tolerant to cryopreservation. Due to the widespread of IVP system worldwide, and increasing demand for vitrification of surplus embryos from cattle producers at increasing distances from IVP laboratories, the development of protocols under less rigorous conditions (i.e. field conditions) remains as a research topic worth exploring (Pereira et al., 2016). Therefore, the objective of this study was to evaluate both pregnancy and delivery rates of in vitro produced (IVP) Nellore (Bos indicus) embryos after vitrification under field conditions.

\section{Materials and Methods}

\section{Oocyte recovery}

Ovum pick-up (OPU) was performed as described by Pereira et al. (2016). Ovarian follicles $>2 \mathrm{~mm}$ diameter were aspirated by ultrasound (DP 2200 VET, Mindray, Nanshan, Shenzhen, China) using a 7.5 Mhz micro transducer convex, vacuum pump (WTA VET), and a 0.9 x $50 \mathrm{~mm}$ hypodermic needle $20 \mathrm{G}$ x 2 " (Terumo Europe, Leuven, Belgium). The needle was connected to a $50 \mathrm{~mL}$ cone through a silicon tube $(0.8$ $\mathrm{m}$ long; $2 \mathrm{~mm}$ internal diameter). The medium used on OPU was TCM-199 (Gibco Life Technologies, Grand Island, NY, USA) supplemented with $25 \mathrm{mM}$ HEPES (Sigma, St Louis, MO, USA), 5\% fetal bovine serum (FBS), $50 \mu \mathrm{g} / \mathrm{mL}$ gentamycin sulfate (Schering-
Plough, São Paulo, SP, Brazil), and $10 \mathrm{IU} / \mathrm{mL}$ sodium heparin (Sigma, St Louis, MO, USA).

\section{In vitro maturation (IVM)}

Only oocytes with normal morphology, with at least 3 compact layers of cumulus cells and homogenous cytoplasm, were used (Pereira et al., 2016). Immediately after, the oocytes were washed 3 times in HEPES-containing TCM-199 medium (Gibco Life Technologies, Grand Island, NY, USA) supplemented with $10 \%$ FBS, $0.20 \mathrm{mM}$ sodium pyruvate and $83.4 \mu \mathrm{g} / \mathrm{mL}$ amycacyn (Sigma, St Louis, MO, USA). For IVM, TCM-199 (Sigma, St Louis, MO, USA) supplemented with 10\% FBS, 1 $\mu \mathrm{g} / \mathrm{mL}$ FSH (Sigma, St Louis, MO, USA), $50 \mu \mathrm{g} /$ $\mathrm{mL}$ hCG, $1 \mu \mathrm{g} / \mathrm{mL} 17-\beta$ estradiol (Sigma, St Louis, MO, USA), $0.20 \mathrm{mM}$ sodium pyruvate (Sigma, $\mathrm{St}$ Louis, MO, USA) and $83.4 \mu \mathrm{g} / \mathrm{mL}$ amycacyn (Sigma, St Louis, MO, USA) were used. Drops $(100 \mu \mathrm{L})$ of embryo culture medium containing 25 to 30 oocytes were placed under mineral oil at $39{ }^{\circ} \mathrm{C}$ in a humid atmosphere of $5 \% \mathrm{CO}_{2}$ during 22 to 26 hours.

\section{In vitro fertilization (IVF)}

The semen used was collected from bulls of proven in vitro fertility. Semen straws $\left(25 \times 10^{6}\right.$ spermatozoa per straw) were thawed for 30 seconds at $35^{\circ} \mathrm{C}$. Semen samples were washed twice by centrifugation at 200 $g$ for 5 minutes in $2 \mathrm{~mL}$ TALP medium supplemented with $10 \mathrm{mM}$ HEPES (Sigma, St Louis, MO, USA), $0.2 \mathrm{mM}$ sodium pyruvate (Sigma, St Louis, MO, USA) and $83.4 \mathrm{~g} / \mathrm{mL}$ amycacyn (Sigma, St Louis, MO, USA). Spermatozoa were capacitated with 10 $\mu \mathrm{g} / \mathrm{mL}$ heparin and motility was stimulated with addition of $18 \mathrm{M}$ penicillamine (Sigma, St Louis, MO, USA), 10 M hypotaurine (Sigma, St Louis, MO, USA), and $8 \mathrm{M}$ epinephrine (Sigma, St Louis, MO, USA) (PHE). After visual appraisal of sperm motility, spermatic concentration was adjusted to $1 \times 10^{6}$ viable spermatozoa $/ \mathrm{mL}$, and placed in medium containing 90 $\mu \mathrm{L}$ TALP-IVF supplemented with $10 \mu \mathrm{g} / \mathrm{mL}$ sodium heparin (Sigma, St Louis, MO, USA) and PHE with $1 \times 10^{5}$ spermatozoa per drop (Viana et al., 2010).

Oocytes were washed 3 times after IVM in preIVF medium composed of TCM-199 (Gibco Life Technologies, Grand Island, NY, USA) supplemented 
with 25 mM HEPES (Sigma, St Louis, MO, USA), and 0.3\% BSA (Sigma, St Louis, MO, USA). Additionally, oocytes were co-incubated with spermatozoa in FERTTALP medium supplemented with $10 \mu \mathrm{g} / \mathrm{mL}$ sodium heparin and PHE under mineral oil at $39{ }^{\circ} \mathrm{C}$ under saturated humidity and $5 \% \mathrm{CO}_{2}$ during 18 to 20 hours.

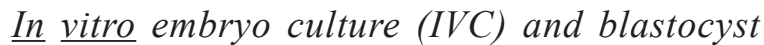 vitrification}

The presumptive zygotes had their cumulus cells removed and were transferred to $100 \mu \mathrm{L}$ drops of culture medium (SOFaa containing $0.5 \% \mathrm{BSA}$ and $2.5 \% \mathrm{FBS}$ ) under mineral oil at $39{ }^{\circ} \mathrm{C}$ in a humid atmosphere of $5 \% \mathrm{CO}_{2}, 5 \% \mathrm{O}_{2}$ and $90 \% \mathrm{~N}_{2}$. Embryo development was assessed on day 3 (D3), day 5 (D5), and day 7 (D7) of IVC. At D3 and D5, 50\% of culture medium was replaced with fresh medium (feeding). Fresh controls were randomly selected $(n=140)$ at day 7 (D7) and transferred to synchronized recipients, as described below.

\section{Blastocyst vitrification}

Blastocysts $(n=130)$ were submitted to vitrification by the "Cryotop" method described by Kuwayama et al. (2005). Grade I initial blastocysts, blastocysts, and expanded blastocysts were placed in 10\% ethylene glycol (EG) (Sigma, St Louis, MO, USA) and 10\% DMSO (Sigma, St Louis, MO, USA) in HEPEScontaining TCM-199 ((Sigma, St Louis, MO, USA) supplemented with 20\% FBS (HTCM-FBS) during 1 minute at room temperature (RT). Embryos were transferred to a vitrification solution containing 20\% EG, 20\% DMSO and 0.5 M sucrose (Sigma, St Louis, MO, USA) for 20 seconds in RT. During this incubation, blastocysts were loaded on top of polypropylene Cryotop tips (3 to 5 embryos) with minimum quantity of vitrification solution and immersed in liquid nitrogen.

\section{Blastocyst warming}

Blastocysts were removed from liquid nitrogen, exposed for 4 seconds in RT and subsequently warmed by immersion of polypropylene Cryotop tip (In Vitro Brasil, Mogi Mirim, Brazil) in medium (TCMHEPES + sucrose) at $35^{\circ} \mathrm{C}$ for 1 minute. Blastocysts were gradually transferred to HTCM-FBS medium containing 0.3 and $0.15 \mathrm{M}$ sucrose (Sigma, St Louis,
MO, USA) during 5 minutes each in RT (Morató et al, 2008; Vajta et al, 2010; Pereira et al, 2016). Embryos were loaded in $0.25 \mathrm{~mL}$ straws with HTCM-FBS medium and transferred to recipients after warming.

\section{Embryo transfer}

Embryo transfer was performed in a fixed-time manner. Recipients received intravaginal progesterone implants (CIDR, Pfizer, Hamilton, New Zealand) and 2 mg estradiol benzoate (Estrogin, Farmavet, São Paulo, SP, Brazil) on day 0. On day 7, recipients received 400 IU equine chorionic gonadotropin (eCG; Sincro $\mathrm{eCG}^{\circledR}$; Ourofino Agronegócio) in association with 150 $\mu \mathrm{g}$ synthetic prostaglandin (D-Cloprostenol; Ciosin ${ }^{\circledR}$; MSD Saúde Animal). The progesterone implant was removed on day 8 , associated with an application of 2 mg estradiol. Before transfer, ovaries were evaluated by transrectal ultrasonography for the detection of corpus luteum (CL). Only recipients with a CL received an embryo on day 17. Pregnancy diagnosis was performed by transrectal ultrasonography on days 35 and 60 after IVF. Furthermore, all pregnancies were monitored monthly until delivery.

\section{Statistical analysis}

Analysis was performed by Fisher's Exact test using Prophet 5.0 Software for Windows 95, considering $5 \%(\mathrm{p}<0.05)$ significance.

\section{Results}

\section{In vitro production of bovine blastocysts}

A total of 750 oocytes were retrieved from 30 donor cows by OPU (mean of 25.0 oocytes/cow). After IVF, 638 presumptive zygotes were cultured $(85.06 \%)$. The cleavage rate was $73.66 \%$ (470/638), and blastocyst development rate at day 7 was $41.37 \%$ (264/638).

Pregnancy and delivery rates after transfer of fresh or vitrified blastocysts

The overall pregnancy rates on days 35 and 60 were similar between embryos transferred either fresh or after vitrification ( $>00.05$; Table 1). Overall pregnancy loss at $60 \mathrm{~d}$ was similar between fresh $(7.69 \%)$ and vitrified embryos $(6.00 \%$; Table 1$)$. 
Table 1. Pregnancy and delivery rates for Nellore (Bos indicus) in vitro-produced embryos transferred fresh or after vitrification.

\begin{tabular}{|c|c|c|c|c|}
\hline \multicolumn{2}{|c|}{ Embryos } & \multirow{2}{*}{$\begin{array}{c}\begin{array}{c}\text { Pregnancy rate } \\
\text { at day } 35\end{array} \\
\mathrm{n}(\%)\end{array}$} & \multirow{2}{*}{$\begin{array}{c}\begin{array}{c}\text { Pregnancy loss } \\
\text { at day } 60\end{array} \\
\mathrm{n}(\%)\end{array}$} & \multirow{2}{*}{$\begin{array}{c}\begin{array}{c}\text { Delivery } \\
\text { rate }\end{array} \\
\mathrm{n}(\%)\end{array}$} \\
\hline Embryo type & Transferred (n) & & & \\
\hline Fresh & 137 & $65(47.44)$ & 5 (7.69) & 60 (43.79) \\
\hline Vitrified & 126 & 50 (39.68) & $3(6.00)$ & $47(37.30)$ \\
\hline
\end{tabular}

No statistical difference was observed between pregnancy rates $(p>0.05)$.

Regarding fresh embryos, the stage of embryonic development affected pregnancy rate at day 35 (Table 2). Blastocysts transferred fresh displayed lower pregnancy rate when compared to expanded blastocysts $(\mathrm{p}<0.05$; Table 2). The pregnancy rate after transfer of vitrified embryos was not affected by the stage of blastocyst development on both time points of development (Table 2). No difference was observed on pregnancy loss between blastocyst and expanded blastocyst stages, irrespectively if transferred fresh or after vitrification (Table 2). Moreover, delivery rates were similar between fresh and vitrified embryos (Table 1).

Table 2. Effect of blastocyst developmental stage on pregnancy rate for Nellore (Bos indicus) in vitro produced embryos transferred fresh or after vitrification.

\begin{tabular}{|c|c|c|c|c|c|c|c|c|}
\hline \multirow[t]{3}{*}{ Developmental stage } & \multicolumn{4}{|c|}{$\begin{array}{c}\text { Pregnancy rate } \\
\text { at day } 35\end{array}$} & \multicolumn{4}{|c|}{$\begin{array}{c}\text { Pregnancy loss } \\
\text { at day } 60\end{array}$} \\
\hline & \multicolumn{2}{|c|}{$\begin{array}{l}\text { Fresh } \\
\text { embryos }\end{array}$} & \multicolumn{2}{|c|}{$\begin{array}{l}\text { Vitrified } \\
\text { embryos }\end{array}$} & \multicolumn{2}{|c|}{$\begin{array}{l}\text { Fresh } \\
\text { embryos }\end{array}$} & \multicolumn{2}{|c|}{$\begin{array}{l}\text { Vitrified } \\
\text { embryos }\end{array}$} \\
\hline & $\mathrm{n}$ & $\%$ & $\mathrm{n}$ & $\%$ & $\mathrm{n}$ & $\%$ & $\mathrm{n}$ & $\%$ \\
\hline Blastocyst & $40 / 96$ & $41.6^{b}$ & $40 / 105$ & 38.0 & $3 / 96$ & $3.1^{\mathrm{a}}$ & $2 / 105$ & $1.9^{a}$ \\
\hline $\begin{array}{l}\text { Expanded } \\
\text { blastocyst }\end{array}$ & $25 / 41$ & $60.9^{a}$ & $10 / 21$ & $47.6^{a}$ & $2 / 41$ & $4.8^{\mathrm{a}}$ & $1 / 21$ & $4.7^{\mathrm{a}}$ \\
\hline
\end{tabular}

Values with different superscript letters $\left({ }^{a, b}\right)$ within the same column indicate significant difference $(p<0.05)$.

\section{Discussion}

Bovine breeds are grouped in two subspecies, namely Bos taurus and Bos indicus, which differ in various aspects of their reproductive physiology, including embryo production potential under in vitro and in vivo conditions (Viana et al., 2010). Differences between these subspecies can also be observed at the gene expression level in preimplantation embryos. Strikingly, these differences are somewhat attenuated by in vitro culture, suggesting a capacity for adaptive plasticity during early development (Wohlres-Viana et al., 2011). Moreover, embryo source (e.g. in vitro or in vivo) is a major factor to embryo cryotolerance (Mucci et al., 2006). It has been shown that IVP embryos have increased lipid content compared to their in vivo counterparts, which is associated with reduced survival after cryopreservation (Sudano et al., 2011).
Vitrification is being widely adopted as an alternative embryo cryopreservation method to conventional freezing, due to its simplicity, reduced costs, and less labor, while dispensing for sophisticated equipment (Vajta et al., 1996). Vitrification is characterized by high concentrations of cryoprotectants (ACP), resulting in high viscosity of the vitrification solution, which leads to physical properties similar to solid compounds, despite the absence of crystallization (Chian et al., 2004).

The data described here demonstrated that vitrification was as efficient as fresh embryos to establish pregnancy in recipient cows. During vitrification, the freezing rate, viscosity and volume of vitrification solution where embryos are placed, are important factors to consider (Arav et al., 2002; Yavin and Arav, 2007). A small volume of embryos 
improves heat transfer, increasing cryopreservation rate (Yavin et al., 2009). The high concentration of cryoprotectants used during vitrification could cause toxicity; however, due to the small volume and short period of exposure to cryoprotectants in the present study, no effect was expected on pregnancy rate.

Our results show that embryos transferred fresh during blastocyst and expanded blastocyst stages contributed differently to the overall pregnancy rate at $35 \mathrm{~d}$. However, this difference was not observed on day 60 , where vitrification was as efficient as fresh embryos. This discrepancy is probably due to the smaller cell number of the blastocysts transferred. Alternatively, the increased time of exposure to supplemented embryo culture medium after warming may have offered increased energy support and higher cellular metabolism that ultimately led to improved embryo quality and higher survival in vivo.

Scanavez et al. (2013) did not observe any effect of developmental stage of IVP embryos (morulae and initial blastocyst) compared to embryos at later stages (blastocyst, expanded blastocyst and hatched blastocyst). In the present study, pairwise comparisons (vitrification and fresh controls) between developmental stages resulted in different pregnancy rates for blastocysts and expanded blastocysts. It is important to note that all blastocysts were transferred at day 7 of development, irrespectively of their developmental stage. Putative differences in cellular metabolism and proliferation between embryonic developmental stages may have resulted in such differences in pregnancy rates of fresh controls.

Pregnancy loss was similar after transfer of blastocysts and expanded blastocysts at $60 \mathrm{~d}$, which disagrees with Andreoti et al. (2009), who reported that embryonic loss of $\mathrm{d} 7$ embryos at earlier stages was higher than more developed embryos. This result is probably due to the variable correlation between embryo development kinetics and developmental potential. Another factor that probably contributed to high pregnancy rates was the improved synchrony between uterine environment and embryonic stage due to embryo transfer in a fixed-time manner (Randi et al., 2015).

In conclusion, both pregnancy and delivery rates of Bos indicus IVP embryos after vitrification under field conditions is indistinguishable from fresh embryos.

\section{Conflict of interest}

The authors declare they have no conflicts of interest with regard to the work presented in this report.

\section{References}

Andreoti M, Spegiorin MR, Cunha CEA. Taxa de prenhez de embriões bovinos tardios transferidos no dia 8 de cultivo. Congresso brasileiro de reprodução animal, Colegio Brasileiro de Reprodução Animal CBRA (Belo Horizonte): Colégio Brasileiro de Reprodução Animal CBRA 2009; 18:352-352.

Arav A, Yavin S, Zeron Y, Natan D, Dekel I, Gacitua H. New trends in gamete's cryopreservation. Mol Cell Endocrinol 2002; 187:77-81. http://www.sciencedirect.com/science/article/pii/ S0303720701007006.

Chian RC, Kuwayama M, Tan L, Tan J, Kato O, Nagai T. High survival rate of bovine oocytes matured in vitro following vitrification. J Reprod Dev 2004; 50:685-696. https://www.jstage. jst.go.jp/article/jrd/50/6/50_6_685/_pdf.

Dattena M, Accardo C, Pilichi S, Isachenko V, Mara L, Chessa B, Cappai P. Comparison of different vitrification protocols on viability after transfer of ovine blastocysts in vitro produced and in vivo derived. Theriogenology 2004; 62:481-493. http://www. sciencedirect.com/science/article/pii/S0093691X03004059.

Kocyigit A, Cevik M. Effects of leukemia inhibitory factor and insulin-like growth factor-I on the cell allocation and cryotolerance of bovine blastocysts. Cryobiology 2015; 71:64-69. http://www. sciencedirect.com/science/article/pii/S0011224015001741.

Kuwayama M, Vajta G, Ied AS, Kato O. Comparison of open and closed meth-ods for vitrification of human embryos and the elimination of potential contamination. Reprod Biomed Online 2005; 11:608-614. http://www.sciencedirect.com/science/article/ pii/S1472648310611698.

Leibo SP, Loskutoff M. Cryobiology of in vitro-derived bovine embryos. Theriogenology 1993; 39:81-94. http://www. sciencedirect.com/science/article/pii/0093691X9390025Z.

Leibo SP, Martino A, Kobayashi S, Pollard JW. Stage dependent sensitivity of oocytes and embryos to low temperatures. Anim Reprod Sci 1996; 42:43-53. http://www.sciencedirect.com/ science/article/pii/0378432096015436.

Mara L, S Casu, A Carta, M Dattena. Cryobanking of farm animal gametes and embryos as a means of conserving livestock genetics. Anim Reprod Sci 2013; 138:25-38. http://www.sciencedirect.com/ science/article/pii/S037843201300047X.

Massip A. Cryopreservation of embryos of farm animals. Reprod Domest Anim 2001; 36:49-55. http://onlinelibrary.wiley.com/ doi/10.1046/j.1439-0531.2001.00248.x/full.

Morató R, Izquierdo D, Paramio MT, Mogas T. Embryo development and struc-tural analysis of in vitro matured bovine 
oocytes vitrified in flexipet denuding pipettes. Theriogenology 2008; 70:1536-1543. https://www.ncbi.nlm.nih.gov/ pubmed/18755504.

Mucci N, Aller J, Kaiser GG, Hozbor F, Cabodevila J, Alberio RH. Effect of estrous cow serum during bovine embryo culture on blastocyst development and cryotolerance after slow freezing or vitrification. Theriogenology 2006; 65:1551-1562. http://www. sciencedirect.com/science/article/pii/S0093691X05003845.

Pereira LC, Ferreira-Silva, JC, Cantanhede LF, Veloso Neto HF, Andrade JC, Moura MT, \& Oliveira MAL (2016). Viability of in vitro produced embryos of gyr cattle (bos indicus) after cryopreservation by vitrification under field conditions. Bol Ind Anim 73(2), 159-164. http://www.iz.sp.gov.br/ pdfsbia/1466788221.pdf.

Prentice JR, Anzar M. Cryopreservation of mammalian oocyte for conservation of animal genetics. Vet Med Int 2010, Article ID 146405. https:/www.hindawi.com/journals/vmi/2011/146405/.

Randi F, Fernandez-Fuertes B, McDonald M, Forde N, Kelly AK, Bastos Amorin H, Muniz de Lima E, Morotti F, Marcondes Seneda M, Lonergan P. Asynchronous embryo transfer as a tool to understand embryo?uterine interaction in cattle: is a large conceptus a good thing? Reprod Fert Dev 2015; 28:1999-2006. http://www.publish.csiro.au/rd/RD15195.

Sanches BV, Marinho LS, Filho BD, Pontes JH, Basso AC, Meirinhos ML, Silva-Santos KC, Ferreira CR, Seneda MM. Cryosurvival and pregnancy rates after exposure of IVFderived Bos indicus embryos to forskolin before vitrification. Theriogenology 2013; 80:372-737. http://www.sciencedirect. com/science/article/pii/S0093691X13001817.

ScanavezAL, Campos CC, Santos RM. Taxa de prenhez e de perda de gestação em receptoras de embriões bovinos produzidos in vitro. Arq Bras Med Vet Zootec 2013; 65:722-728. http://www.scielo.br/ scielo.php?script=sci_arttext\&pid=S0102-09352013000300017.

Sudano MJ, Paschoal DM, Rascado TS, Magalhães LCO, Crocomo LF, Lima-Neto JF, Landim-Alvarenga FC. Lipid content and apoptosis of in vitro-produced bovine embryos as determinants of susceptibility to vitrification. Theriogenology 2011; 75:1211-1220. http://www.sciencedirect.com/science/ article/pii/S0093691X10006266.
Vajta G, Holm P, Kuwayama M, Booth PJ, Jacobsen H, Greve T, Callesen H. Open pulled straw (ops) vitrification: a new way to reduce cryoinjuries of bovine ova and embryos. Mol Reprod Dev 2010; 51:53-58. http://onlinelibrary.wiley.com/ doi/10.1002/(SICI)1098-2795(199809)51:1\%3C53::AIDMRD6\%3E3.0.CO;2-V/epdf.

Vajta G, Kuwayama M. Improving cryopreservation systems. Theriogenology 2006; 65:236-244. http://www.sciencedirect. com/science/article/pii/S0093691X05004164.

Vajta G, Holm P, Greve T, Callesen H. Factors affecting survival rates of in vitro produced bovine embryos after vitrification and direct in-straw rehydration. Anim Reprod Sci 1996; 45(3):191-200. http://www.sciencedirect.com/science/article/pii/ S0378432096015837.

Viana JHM, Siqueira LGB, Palhão MP, Camargo LSA. Use of in vitro fertilization technique in the last decade and its effect on Brazilian embryo industry and animal production. Acta Sci Vet 2010; 38:661-674. http://www.ufrgs.br/actavet/38-suple-2/23 SBTE_JHENRIQUE.pdf.

Visintin JA, Martins JFP, Bevilacqua EM, Mello MRB, Nicácio AC, Assumpção MEOA. Cryopreservation of Bos taurus vs Bos indicus embryos: are they really different? Theriogenology 2002; 57:345-359. http://www.sciencedirect.com/science/article/pii/ S0093691X01006756.

Wohlres-Viana AS, Pereira MM, Viana JHM, Machado MA, Camargo LSA. Comparison of gene expression in Bos indicus and Bos taurus embryos produced in vivo or in vitro. Livest Sci 2011; 140:62-67. http://www.sciencedirect.com/science/article/ pii/S1871141311000679.

Yavin S, Arav A. Measurement of essential physical properties of vitrification so-lutions. Theriogenology 2007; 67:81-89. http://www.sciencedirect.com/science/article/pii/ S0093691X06005036.

Yavin S, Aroyo A, Roth Z, Arav A. Embryo cryopreservation in the presence of low concentration of vitrification solution with sealed pulled straws in liquid ni-trogen slush. Hum Reprod 2009; 24:797804. https://academic.oup.com/humrep/article/24/4/797/630673/ Embryo-cryopreservation-in-the-presence-of-low. 